\title{
Concretes with binary mixtures of artificial pozzolans and concrete demolition waste
}

\author{
Concretos com misturas binárias de pozolanas artificiais e \\ resíduos de demolição de concreto
}

\section{Cristian Jonathan Franco de Lima Francisco Roger Carneiro Ribeiro Geraldo Cechella Isaia Mauricio Mancio}

\begin{abstract}
$\mathbf{T}$ he objective of this study is to analyse the use of binary mixtures of pozzolanic materials and concrete demolition waste in concrete mixtures, especially the resulting mechanical properties and durability.

A total of ten concrete formulations were produced distinguishing them in different types using different Portland cements, different artificial pozzolans and coarse aggregates from concrete demolition. The particular properties of each formulation were verified by testing the axial compressive strength, longitudinal modulus of elasticity and penetration of chloride under immersion. Substitutions were of $15 \%$ w.t. and $30 \%$ w.t. natural coarse aggregate substituted with concrete demolition waste and, in the case of binary mixtures, additional $25 \%$ w.t. of the binder agglomerate substituted with rice husk ash or fly ash. Results showed that the final strength to axial compression and modulus of elasticity of concrete mixtures were negatively affected by utilising demolition waste, but this effect was balanced by adding supplementary cementitious materials. Regarding the durability test, it was found that the lowest coefficients occurred in the mixtures using CP V-ARI, together with artificial pozzolans, in mixtures with $15 \%$ w.t. substitution of natural aggregate with recycled aggregate. It was concluded that using recycled aggregates in concrete is viable but conditioned to the concomitant use of pozzolanic materials.
\end{abstract}

Keywords: Concrete. Rice husk ash. Fly ash. Demolition waste. Binary mixtures.

\section{Resumo}

${ }^{1}$ Cristian Jonathan Franco de

${ }^{1}$ Universidade do Vale do Rio dos Sinos São Leopoldo - RS - Brasil

${ }^{2}$ Francisco Roger Carneiro

Ribeiro

2Universidade do Vale do Rio dos Sinos São Leopoldo - RS - Brasil

${ }^{3}$ Geraldo Cechella Isaia ${ }^{3}$ Universidade Federal de Santa Maria Santa Maria - RS - Brasil

${ }^{4}$ Mauricio Mancio ${ }^{4}$ Universidade do Vale do Rio dos Sinos São Leopoldo - RS - Brasil

Recebido em 28/01/20 Aceito em 11/05/20

A presente investigação objetiva analisar a utilização de materiais pozolânicos e resíduos de demolição de concreto nas propriedades mecânicas e de durabilidade em concretos com misturas binárias. Foram produzidas dez formulações, distinguindo-as em diferentes traços com o uso de diferentes cimentos Portland, diferentes pozolanas e agregados graúdos da demolição de concretos, a fim de verificar suas particularidades através dos ensaios de resistência à compressão axial, módulo de elasticidade longitudinal e penetração de íons cloreto por imersão. As substituições de materiais se deram em 15 e $30 \%$ do agregado graúdo natural por resíduos de demolição de concreto e em substituições de $25 \%$ do aglomerante por cinza de casca de arroz e cinza volante para as misturas binárias. Os resultados evidenciaram que nos testes de resistências à compressão axial e módulo de elasticidade dos concretos, os valores finais foram afetados pelo uso dos resíduos de demolição, todavia balanceados com o uso dos materiais cimentícios suplementares. Quanto ao ensaio de durabilidade, verificou-se que os menores coeficientes ocorreram nos traços com a utilização do CP V-ARI, juntamente com as pozolanas, nas misturas com substituições parciais do agregado natural por agregado reciclado em 15\%. Pôde-se concluir, contudo, a viabilidade da utilização de agregados reciclados em concretos, porém condicionados com o uso concomitante de materiais pozolânicos.

Palavras-chave: Concreto. Cinzas de casca de arroz. Cinzas volantes. Resíduos de demolição. Misturas binárias.

LIMA, C. J. F. de; RIBEIRO, F. R. C.; ISAIA, G. C.; MANCIO, M. Concretes with binary mixtures of artificial pozzolans and concrete demolition waste. Ambiente Construído, Porto Alegre, v. 20, n. 4, p. 177-188, out./dez. 2020. ISSN 1678-8621 Associação Nacional de Tecnologia do Ambiente Construído.

http://dx.doi.org/10.1590/s1678-86212020000400466 


\section{Introduction}

Using concrete in construction and engineering works is widespread and estimated at approximately 20 billion metric tons per year (WANG et al., 2017). This high use results in a substantial demand for cement which is its principal constituent. The global demand for cement is estimated at 4 billion metric tons per year, of which 40 million tons were the estimated demand in Brazil in 2019 (U.S. GEOLOGICAL..., 2019; SINDICATO..., 2019). According to Chen et al. (2017) and Huang et al. (2018), the cement industry generates about $8 \%$ of global carbon dioxide $\left(\mathrm{CO}_{2}\right)$ emissions. As such, the carbon footprint of this cement demand is bound to have negative environmental effects.

Furthermore, Blankendaal, Schuur and Voordijk (2014) raise serious concerns regarding environmental damage and destruction of the ecological equilibrium of cement use. Additionally, if there is no appropriate recycling of waste, most industrial by-products are incinerated resulting in contamination and atmospheric pollution (XUAN; POON; ZHENG, 2018).

The International Energy Agency (IEA) and World Business Council for Sustainable Development (WBCSD) released a Cement Technology Roadmap in which four strategies are listed so that the cement industry can reduce $\mathrm{CO}_{2}$ emissions by 2050. These strategies are electrical and thermal efficiency; alternative fuels; clinker substitution and carbon capture and sequestering. Regarding electrical and thermal efficiency, Schneider (2015) states that kiln efficiency is already at a limit. On the other hand, clinker substitution can produce more immediate results with a potential reduction of $25 \%$ to $30 \%$ in $\mathrm{CO}_{2}$ emissions. However, if this strategy is taken to its maximum potential, sources of supplementary cement materials (SCMs) could become scarce (DIAZ-LOYA et al., 2019).

In the current scenario, alternatives have been used to reduce the environmental impact of cement use and improper handling of waste. One solution has been to use clinker substitution with several artificial pozzolans, for example: fly ash (FA), rice husk ash (RHA), active silica etc. Medina et al. (2018) points out that, in binary mixtures with distinct additions, SCMs are beneficial as long as there is a balance between substitution proportions and performance, which are in turn dependent on physio-chemical characteristics of the SCMs. These characteristics interact differently in the concrete paste and influence its microstructure so that the resulting concrete has distinct mechanical and durability properties (ISAIA; FURQUIM; GASTALDINI, 2009).

Concrete demolition waste (CDW) recycling can reduce the expenditure of natural raw materials. However, when used in concrete mixtures, CDW can reduce mechanical strength and increase porosity and water absorption. The degree of these effects depends on the level of substitution, production technique for the aggregate concrete and the inter-surface transition zone (KOU; POON, 2015; ISAIA et al., 2017). Despite these limitations, Santos and Leite (2018) demonstrated that concretes with up to $40 \%$ recycled coarse aggregate could be made viable with compressive strength in accordance to stipulated levels from mixing ratios, improved density and adherence between cement and aggregates. An alternative form or CDW reuse was demonstrated by Kalinowska-Wichrowska, Pawluczuk and Boltryk (2020). In this case recycled mortar is mechanically and heat-treated in an apparatus which produces high-quality recycled concrete aggregate.

Based on these facts, the objectives of this study were to analyze the mechanical properties of axial compressive strength and elasticity modulus in concretes with:

(a) partial substitution of natural coarse aggregate (NCA) with aggregate from concrete demolition waste; and

(b) partial substitution of different Portland cements with rice husk ash or fly ash.

\section{Materials and methods}

Four types of materials were used in this study: CP IV - 32, CP V - ARI, RHA and FA. CP V - ARI cement is particularly suitable to test the effect of partial substitution of binders because it has a low level of mineral admixtures. On the other hand, substitution was not applied to CP IV as it already contains pozzolans in its composition. Supplementary cement materials were chemically characterised according to NBR 12653 (ABNT, 2015a) and ground in a ball mill for 1 hour. The physio-chemical characteristics of the materials are presented in Tables 1 and 2, respectively.

178 Lima, C. J. F. de; Ribeiro, F. R. C.; Isaia, G. C.; Mancio, M. 
Table 1 - Physical characteristics of cements and artificial pozzolans

\begin{tabular}{l|l|l|l|l}
\hline \multicolumn{1}{c|}{ Physical Characteristic } & CP IV - 32 & CP V - ARI & RHA & FA \\
\hline Density $\left({\left.\mathrm{g} . \mathrm{cm}^{-3}\right)}^{2}\right.$ & 2.70 & 3.14 & 2.09 & 2.19 \\
BET specific area $\left(\mathrm{m}^{2} . \mathrm{g}^{-1}\right)$ & 3.11 & 5.96 & 18.71 & 3.55 \\
Content of fines, \#0.075 mm (\% left) & 0.20 & 0.02 & 4.97 & 2.11 \\
Normal consistency (\%) & 30.00 & 29.10 & - & - \\
Initial setting time (min) & 200 & 154 & - & - \\
Final setting time (min) & 239 & 191 & - & - \\
Age (days) & Axial Compressive Strength (MPa) \\
3 & 21.0 & 38.1 & - & - \\
7 & 25.3 & 38.6 & - & - \\
28 & 33.1 & 50.0 & - & - \\
\hline
\end{tabular}

Table 2 - Chemical characteristics of cements and artificial pozzolans

\begin{tabular}{l|c|c|c|c}
\hline \multicolumn{1}{c|}{ Chemical characteristic } & CP IV - 32 & CP V - ARI & RHA & FA \\
\hline Loss on ignition (LOI) (\% w.t.) & 7.00 & 3.08 & 0.25 & 1.00 \\
Total silicon dioxide $\left(\mathrm{SiO}_{2}\right)(\%$ w.t.) & 32.10 & 18.81 & 94.84 & 65.50 \\
Aluminium oxide $\left(\mathrm{Al}_{2} \mathrm{O}_{3}\right)(\%$ w.t.) & 8.79 & 4.75 & 0.39 & 25.89 \\
Iron oxide $\left(\mathrm{Fe}_{2} \mathrm{O}_{3}\right)(\%$ w.t.) & 4.34 & 2.68 & 0.54 & 3.15 \\
Total calcium oxide $(\mathrm{CaO})(\%$ w.t.) & 38.12 & 60.88 & 1.32 & 0.34 \\
Magnesium oxide $(\mathrm{MgO})(\%$ w.t.) & 5.04 & 5.22 & 0.4 & 1.53 \\
Sulfuric anhydride $\left(\mathrm{SO}_{3}\right)(\%$ w.t.) & 1.97 & 2.28 & 0.01 & - \\
Sodium oxide $\left(\mathrm{Na}_{2} \mathrm{O}\right)(\%$ w.t.) & 0.20 & 0.18 & 0.11 & 0.21 \\
Potassium oxide $\left(\mathrm{K}_{2} \mathrm{O}\right)(\%$ w.t.) & 1.39 & 0.89 & 1.45 & 1.98 \\
Free calcium oxide $(\mathrm{CaO}$ free $)(\%$ w.t.) & 1.93 & 1.17 & - & - \\
Insoluble residue $(\mathrm{IR})(\%$ w.t.) & 34.27 & 1.19 & - & - \\
Carbon dioxide $\left(\mathrm{CO}_{2}\right)(\%$ w.t.) & 4.89 & 2.27 & - & - \\
\hline
\end{tabular}

Furthermore, the aggregates used in this study were:

(a) coarse aggregate from basalt (gravel);

(b) natural fine aggregate (sand); and

(c) concrete demolition waste $(\mathrm{CDW})$ aggregate from the production of interlocking concrete pavers.

The physical characteristics of the aggregates are shown in Table 3.

The water used fo concrete mixtures was municipal tap water. A plasticiser chemical admixture MasterGlenium54 - with chemical characteristics shown in Table 4 was added to the water to improve workability of the concrete paste.

The mineralogical characterisation of the supplementary cementitious materials was obtained through X-ray Diffraction (XRD) as shown in Figure 1.

Concrete mixing ratios were based in theoretical and experimental studies following the methods proposed by Helene and Terzian (1992) in order to obtain suitable results for workability, additive ratio, mixing time and Abrams law curve. Chosen parameters were characteristic axial compressive strengths of $25 \mathrm{MPa}$ and 35 $\mathrm{MPa}$, two types of Portland cement with water/binder ratios (w/b) of $0.30,0.475$ and 0.65 and slump test results of $100 \pm 20 \mathrm{~mm}$. Furthermore, the water/dry materials ratio was defined as $8.22 \%$ and the dry mortar ratio as 0.50 so that mass-based mixing ratios in the format (cement:sand:gravel: $\mathrm{w} / \mathrm{b}$ ) could be determined.

According to NBR 12655 (ABNT, 2015b) and assuming a standard deviation of $4 \mathrm{MPa}$, average strengths for the mixtures after 28 days were $31.6 \mathrm{MPa}$ and $41.6 \mathrm{MPa}$ for the pre-defined characteristic strengths of 25 $\mathrm{MPa}$ and $35 \mathrm{MPa}$, respectively. Each cement mixture was moulded into cylindrical test specimens $(\varnothing 10 \mathrm{~cm} \mathrm{x}$ $20 \mathrm{~cm}$ ) following NBR 5738 (ABNT, 2016). There were 3 mixture ratios for each concrete mixture and 3 samples were prepared for each mixing ratio. Samples were water cured for 28 days after which axial compressive strength tests were performed according to NBR 5739 (ABNT, 2018) procedures. The Tab;e 5 shows these results. 
Table 3 - Physical characteristics of aggregates

\begin{tabular}{l|c|c|c}
\hline \multicolumn{1}{c|}{ Physical characteristic } & $\begin{array}{c}\text { Fine aggregate } \\
\text { (sand) }\end{array}$ & $\begin{array}{c}\text { Coarse aggregate } \\
\text { (gravel) }\end{array}$ & $\begin{array}{c}\text { CDW } \\
\text { aggregate }\end{array}$ \\
\hline Density $\left(\mathrm{g} . \mathrm{cm}^{-3}\right)$ & 2.65 & 2.49 & 2.16 \\
Bulk density $\left(\mathrm{g} . \mathrm{cm}^{-3}\right)$ & 1.57 & 1.36 & 1.01 \\
Fineness module & 2.19 & 6.96 & 6.79 \\
Characteristic max diameter $(\mathrm{mm})$ & 2.36 & 19 & 19 \\
Water absorption $(\%)$ & 0.33 & 2.18 & 5.05 \\
Form index & - & 1.59 & 2.04 \\
\hline
\end{tabular}

Table 4 - Chemical additive characterization

Source: BASF (2017)

\begin{tabular}{l|c}
\hline Characteristics & MasterGlenium54 \\
\hline Density $\left(\mathrm{g} \cdot \mathrm{cm}^{-3}\right)$ & 1.10 \\
$\mathrm{pH}$ & 6 \\
Solid portion $(\%)$ & 40 \\
Base chemical & Polycarboxylate ether \\
Appearance & Yellowish liquid \\
\hline
\end{tabular}

Figure 1 - X-ray Diffraction (XRD) of artificial pozzolans: RHA and FA

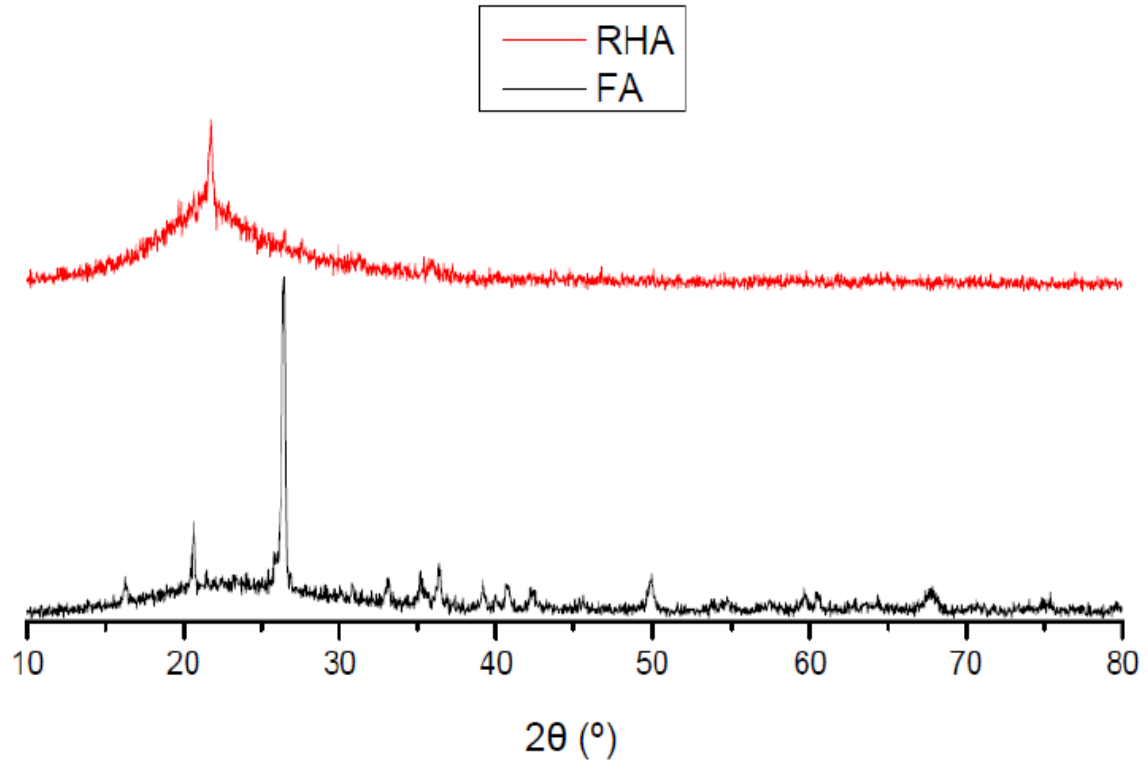

Based on the results shown in Table 5, Abrams Law curves were plotted and exponential expressions were determined as shown in Figure 2 and Table 6 . Table 6 also displays the coefficient of determination $\mathrm{R}^{2}$ and the water to binder ratios for each axial strength value.

Abram's law curves allowed the determination of the definitive concrete mixture ratios shown in Table 7 . Samples prepared according to these ratios were subjected to axial compressive strength tests in accordance with NBR 5739 (ABNT, 2018), modulus of elasticity tests in accordance to NBR 8522 (ABNT, 2017) and penetration from immersion in chloride ion in accordance with Otsuki, Nagataki and Nakashita (1992) and Wee, Suryavanshi and Tin (2000). In addition, the statistical analysis for assessing the durability of concretes was performed using the parametric ANOVA test (two-way). 
Table 5 - Mixing ratios, axial compressive strength and slump after 28 days curing

\begin{tabular}{|c|c|c|c|c|c|c|c|c|c|c|c|}
\hline \multirow[b]{2}{*}{$\begin{array}{l}\text { Concrete } \\
\text { mixtures }\end{array}$} & \multirow[b]{2}{*}{$\begin{array}{l}\text { w/b } \\
\text { ratio }\end{array}$} & \multicolumn{6}{|c|}{ Mixing ratio } & \multirow[b]{2}{*}{$\begin{array}{l}\text { Additive } \\
\qquad(\%)\end{array}$} & \multirow{2}{*}{$\begin{array}{l}\text { Average } \\
\text { axial } \\
\text { strength } \\
(\mathrm{MPa})\end{array}$} & \multirow[b]{2}{*}{$\begin{array}{l}\text { Standard } \\
\text { Deviation }\end{array}$} & \multirow[b]{2}{*}{$\begin{array}{c}\text { Slump } \\
(\mathrm{mm})\end{array}$} \\
\hline & & Cement & RHA & FA & Sand & Gravel & CDW & & & & \\
\hline \multicolumn{12}{|c|}{ CP V - ARI } \\
\hline \multirow{3}{*}{ REF. } & 0.30 & 1.00 & - & - & 1.13 & 2.13 & - & 0.12 & 63.10 & 0.898 & 90 \\
\hline & 0.475 & 1.00 & - & - & 1.89 & 2.89 & - & 0.10 & 43.20 & 0.327 & 90 \\
\hline & 0.65 & 1.00 & - & - & 2.95 & 3.95 & - & - & 32.10 & 0.245 & 90 \\
\hline \multirow{3}{*}{$15 \% \mathrm{CDW}$} & 0.30 & 1.00 & - & - & 1.13 & 1.81 & 0.32 & 0.15 & 37.90 & 0.580 & 80 \\
\hline & 0.475 & 1.00 & - & - & 1.89 & 2.46 & 0.43 & 0.10 & 34.30 & 0.539 & 110 \\
\hline & 0.65 & 1.00 & - & - & 2.95 & 3.36 & 0.59 & - & 28.50 & 0.416 & 110 \\
\hline \multirow{3}{*}{$30 \% \mathrm{CDW}$} & 0.30 & 1.00 & - & - & 1.13 & 1.49 & 0.64 & 0.16 & 35.10 & 0.098 & 90 \\
\hline & 0.475 & 1.00 & - & - & 1.89 & 2.02 & 0.87 & 0.12 & 28.80 & 0.515 & 80 \\
\hline & 0.65 & 1.00 & - & - & 2.95 & 2.77 & 1.18 & - & 22.10 & 0.670 & 110 \\
\hline \multirow{3}{*}{$\begin{array}{l}15 \% \text { CDW } \\
25 \% \text { RHA }\end{array}$} & 0.30 & 0.75 & 0.25 & - & 1.02 & 1.81 & 0.32 & 0.30 & 69.10 & 0.841 & 110 \\
\hline & 0.475 & 0.75 & 0.25 & - & 1.78 & 2.46 & 0.43 & 0.20 & 49.90 & 0.964 & 80 \\
\hline & 0.65 & 0.75 & 0.25 & - & 2.85 & 3.36 & 0.59 & 0.15 & 40.50 & 1.249 & 80 \\
\hline \multirow{3}{*}{$\begin{array}{l}30 \% \text { CDW } \\
25 \% \text { RHA }\end{array}$} & 0.30 & 0.75 & 0.25 & - & 1.02 & 1.49 & 0.64 & 0.35 & 56.00 & 1.135 & 100 \\
\hline & 0.475 & 0.75 & 0.25 & - & 1.78 & 2.02 & 0.87 & 0.25 & 45.50 & 0.621 & 100 \\
\hline & 0.65 & 0.75 & 0.25 & - & 2.85 & 2.77 & 1.18 & 0.15 & 32.10 & 0.849 & 80 \\
\hline \multirow{3}{*}{$\begin{array}{l}15 \% \text { CDW } \\
25 \% \text { FA }\end{array}$} & 0.30 & 0.75 & - & 0.25 & 1.04 & 1.81 & 0.32 & 0.25 & 67.90 & 0.980 & 110 \\
\hline & 0.475 & 0.75 & - & 0.25 & 1.80 & 2.46 & 0.43 & 0.15 & 51.10 & 0.939 & 80 \\
\hline & 0.65 & 0.75 & - & 0.25 & 2.86 & 3.36 & 0.59 & 0.10 & 32.90 & 0.694 & 90 \\
\hline \multirow{3}{*}{$\begin{array}{l}30 \% \mathrm{CDW} \\
25 \% \mathrm{FA}\end{array}$} & 0.30 & 0.75 & - & 0.25 & 1.02 & 1.81 & 0.32 & 0.20 & 55.40 & 0.604 & 90 \\
\hline & 0.475 & 0.75 & - & 0.25 & 1.78 & 2.46 & 0.43 & 0.15 & 35.20 & 0.523 & 80 \\
\hline & 0.65 & 0.75 & - & 0.25 & 2.85 & 3.36 & 0.59 & 0.10 & 27.50 & 0.457 & 100 \\
\hline \multicolumn{12}{|c|}{ CP IV - 32} \\
\hline \multirow{3}{*}{ REF. } & 0.30 & 1.00 & - & - & 1.13 & 2.13 & - & 0.25 & 52.50 & 0.955 & 100 \\
\hline & 0.475 & 1.00 & - & - & 1.89 & 2.89 & - & 0.15 & 35.40 & 0.547 & 80 \\
\hline & 0.65 & 1.00 & - & - & 2.95 & 3.95 & - & - & 19.70 & 0.710 & 80 \\
\hline \multirow{3}{*}{$15 \% \mathrm{CDW}$} & 0.30 & 1.00 & - & - & 1.13 & 1.81 & 0.32 & 0.20 & 45.60 & 0.555 & 90 \\
\hline & 0.475 & 1.00 & - & - & 1.89 & 2.46 & 0.43 & 0.15 & 32.80 & 0.637 & 90 \\
\hline & 0.65 & 1.00 & - & - & 2.95 & 3.36 & 0.59 & - & 19.40 & 0.425 & 80 \\
\hline \multirow{3}{*}{$30 \% \mathrm{CDW}$} & 0.30 & 1.00 & - & - & 1.13 & 1.49 & 0.64 & 0.22 & 36.90 & 0.400 & 90 \\
\hline & 0.475 & 1.00 & - & - & 1.89 & 2.02 & 0.87 & 0.10 & 27.40 & 0.482 & 80 \\
\hline & 0.65 & 1.00 & - & - & 2.95 & 2.77 & 1.18 & - & 18.30 & 0.335 & 80 \\
\hline
\end{tabular}

Figure 2 - Abrams Law Curves at 28 days

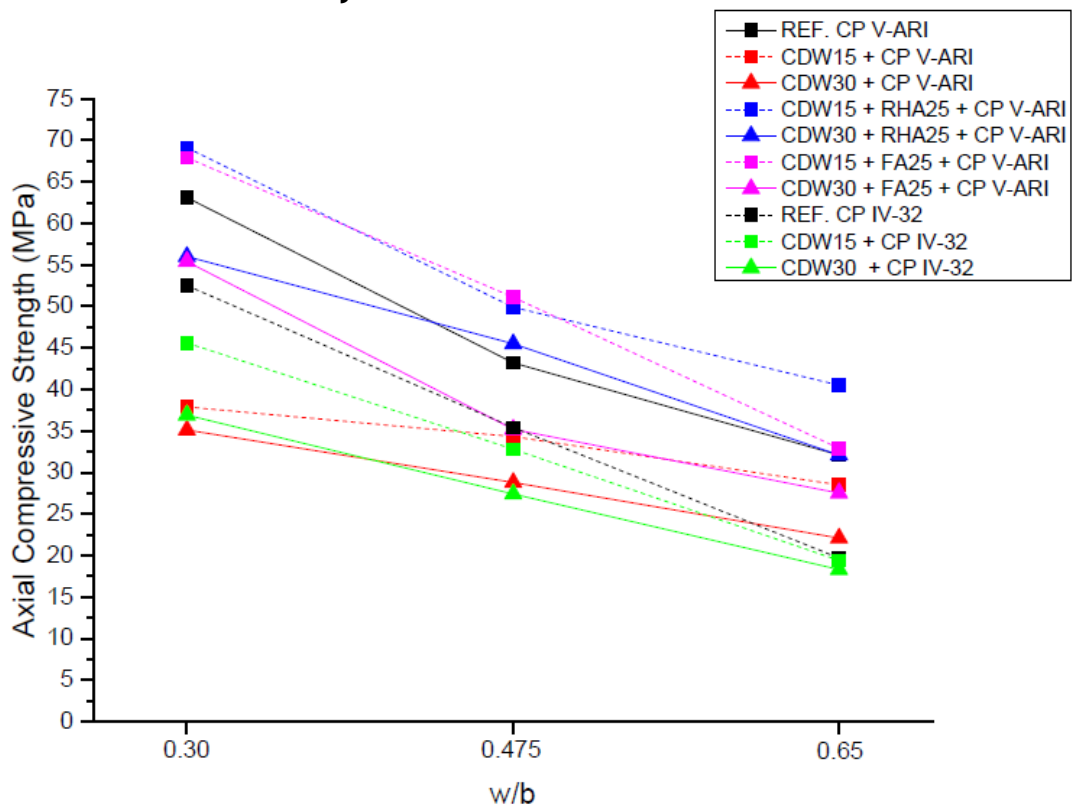


Table 6 - Abrams curve equations, coefficient of determination $R^{2}$ and $w / b$ ratios

\begin{tabular}{l|c|c|c|c}
\hline \multicolumn{1}{c|}{ Concrete mixtures } & $\mathbf{f c}$ & $\mathbf{R}^{2}$ & $\begin{array}{c}\mathbf{w} / \mathbf{b} \\
\mathbf{( 3 1 . 6} \mathbf{M P a})\end{array}$ & $\begin{array}{c}\mathbf{w} / \mathbf{b} \\
\mathbf{( 4 1 . 6 ~ M P a})\end{array}$ \\
\hline REF. CP V - ARI & $\mathrm{fc}=132.06 \mathrm{e}^{-2.217 \mathrm{a} / \mathrm{c}}$ & 0.9728 & - & 0.54 \\
CDW 15 + CP V - ARI & $\mathrm{fc}=53.370 \mathrm{e}^{-0.957 \mathrm{a} / \mathrm{c}}$ & 0.9943 & 0.55 & - \\
CDW 30 + CP V - ARI & $\mathrm{fc}=60.059 \mathrm{e}^{-1.540 \mathrm{a} / \mathrm{c}}$ & 0.9998 & 0.42 & - \\
CDW 15 + RHA 25 + CP V - ARI & $\mathrm{fc}=122.24 \mathrm{e}^{-1.743 \mathrm{a} / \mathrm{c}}$ & 0.9517 & - & 0.62 \\
CDW 30 + RHA 25 + CP V - ARI & $\mathrm{fc}=108.53 \mathrm{e}^{-1.864 \mathrm{a} / \mathrm{c}}$ & 0.9975 & - & 0.53 \\
CDW 15 + FA 25 + CP V - ARI & $\mathrm{fc}=159.56 \mathrm{e}^{-2.422 \mathrm{a} / \mathrm{c}}$ & 0.9992 & - & 0.57 \\
CDW 30 + FA 25 + CP V - ARI & $\mathrm{fc}=115.43 \mathrm{e}^{-2.275 a / c}$ & 0.9316 & - & 0.47 \\
REF. CP IV - 32 & $\mathrm{fc}=165.96 \mathrm{e}^{-3.273 \mathrm{a} / \mathrm{c}}$ & 0.9997 & 0.53 & - \\
CDW 15 + CP IV - 32 & $\mathrm{fc}=125.29 \mathrm{e}^{-2.859 \mathrm{a} / \mathrm{c}}$ & 0.9987 & 0.50 & - \\
CDW 30 + CP IV - 32 & $\mathrm{fc}=83.396 \mathrm{e}^{-2.336 \mathrm{a} / \mathrm{c}}$ & 0.9999 & 0.42 & - \\
\hline
\end{tabular}

Table 7 - Definitive mixing ratios obtained from Abrams Law Curves

\begin{tabular}{l|c|c|c|c|c|c|c|c|c}
\hline \multirow{2}{*}{ Concrete mixtures } & \multicolumn{5}{|c|}{ Mixing ratio } & w/b & $\begin{array}{c}\text { Cement } \\
\text { consumption } \\
\left(\mathbf{k g . m}^{-3}\right)\end{array}$ & $\begin{array}{c}\text { Additive } \\
(\%)\end{array}$ \\
\cline { 2 - 9 } & Cement & RHA & FA & Sand & Gravel & CDW & & \\
\hline REF. CP V - ARI & 1.00 & - & - & 2.28 & 3.28 & - & 0.54 & 329.37 & - \\
CDW 15 + CP V - ARI & 1.00 & - & - & 2.35 & 2.85 & 0.50 & 0.55 & 317.22 & 0.10 \\
CDW 30 + CP V - ARI & 1.00 & - & - & 1.55 & 1.78 & 0.77 & 0.42 & 412.01 & 0.10 \\
CDW 15 + RHA 25 + & 0.75 & 0.25 & - & 2.67 & 3.20 & 0.57 & 0.62 & 280.97 & 0.12 \\
CP V - ARI & & & & & & & & & \\
CDW 30 + RHA 25 + & 0.75 & 0.25 & - & 2.12 & 2.25 & 0.97 & 0.53 & 324.47 & 0.15 \\
CP V - ARI & & & & & & & & & \\
CDW 15 + FA 25 + CP & 0.75 & - & 0.25 & 2.38 & 2.95 & 0.52 & 0.57 & 305.95 & 0.12 \\
V - ARI & & & & & & & & & \\
CDW 30 + FA 25 + CP & 0.75 & - & 0.25 & 1.77 & 2.00 & 0.86 & 0.47 & 366.50 & 0.15 \\
V - ARI & 1.00 & - & - & 2.22 & 3.22 & - & 0.53 & 329.89 & - \\
REF. CP IV - 32 & 1.00 & - & - & 2.04 & 2.58 & 0.46 & 0.50 & 343.80 & 0.10 \\
CDW 15 + CP IV - 32 & 1.00 & - & - & 1.55 & 1.78 & 0.77 & 0.42 & 403.38 & 0.10 \\
CDW 30 + CP IV - 32 & 1.00
\end{tabular}

\section{Analysis and discussion of results}

\section{Axial compressive strength}

Axial compressive strength is one of the most important properties to be measured in hardened concrete. Satisfactory strength levels are a reflection of the quality of materials used. Figure 3 shows average results from 80 test specimens after 28 and 91 days of curing.

Figure 3 shows that concrete mixtures aged 28 days reached axial compressive strengths within predicted parameters. These corresponded to values within an interval of $f_{28}=31.6 \pm 5 \%$ and $f_{28}=41.6 \pm 5 \%$ with the best results for samples that contained artificial pozzolans in the mixture. Increasing the curing time to 91 days resulted in increases in strength with an average increase of $14.82 \%$. This result suggested that increases in strengths could be related to the grinding process of the ashes since smaller particle sizes tend to favour nucleation of hydration compounds. Strength of mixtures which contained only CDW and CP V ARI decreased with increasing aggregate substitution for both 28 days and 91 days. Similar reductions in strength were observed for mixtures which contained only CDW and CP IV, despite this type of cement containing pozzolanic material in its composition. According to Leite (2001) and Ryu (2002), the reduction in strength could be attributed to:

(a) larger specific surface of recycled aggregates;

(b) weakness of the transition zone in the matrix of recycled material and aggregate; and

(c) usage of dry aggregates and their higher porosity and water absorption.

182 Lima, C. J. F. de; Ribeiro, F. R. C.; Isaia, G. C.; Mancio, M. 
Figure 3 - Axial compressive strengths at different ages and different levels of concrete strength

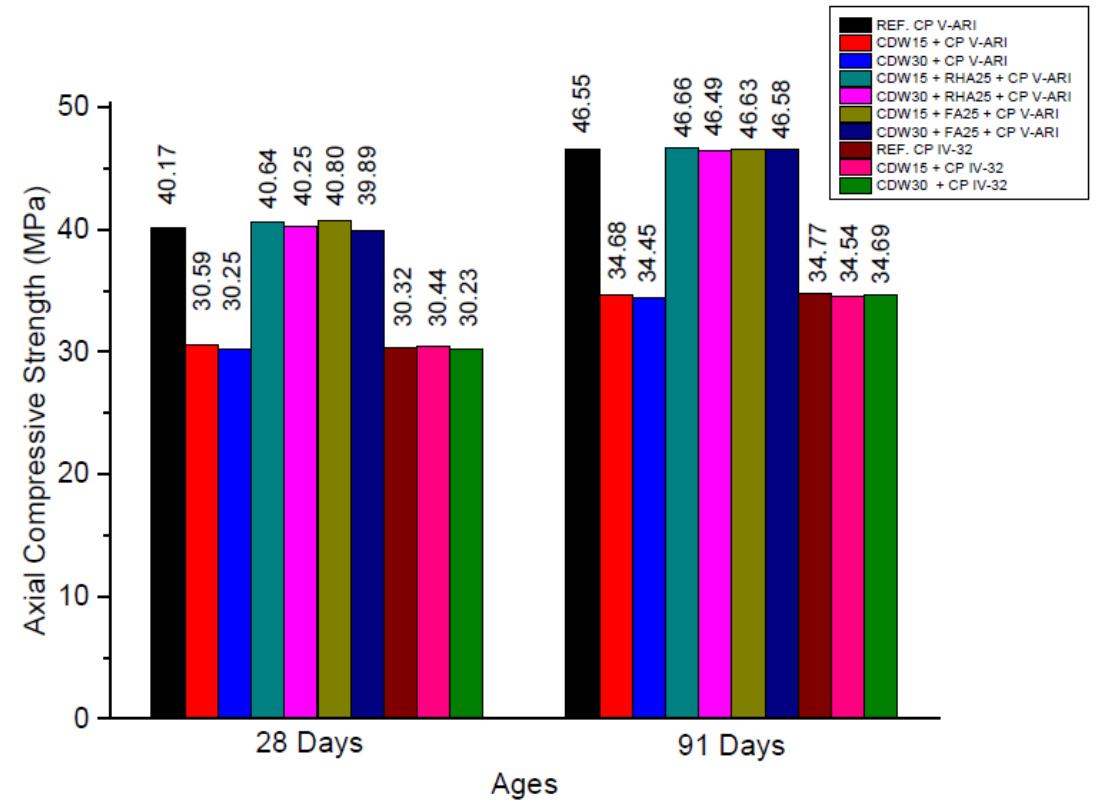

Figure 3 also shows that strength increases with $25 \%$ w.t. substitution of agglomerates with artificial pozzolanic materials regardless of curing time or w/b ratio. This can be explained in several ways as reported by Li, Xiao and Zhou (2009) and Kou and Poon (2013): interface zone improvement; increased density brought by pozzolan insertion in the interspace of recycled aggregates and improvement of interspace microstructure. This results in better workability and compressive strength of the mixtures and is brought about by increased binding between artificial pozzolans and aggregates.

Average strength of the reference mixture was $40.17 \mathrm{MPa}$ for a $\mathrm{w} / \mathrm{b}=0.54$. The average strength of the mixtures without artificial pozzolans was $30.42 \mathrm{MPa}$ with an average w/b $=0.48$, which represents a $24.27 \%$ reduction in strength and a decrease of $11.11 \%$ in water usage and might have impaired workability. On the other hand, the average strength of mixtures with artificial pozzolans was $40.40 \mathrm{MPa}$ with an average w/b= 0.55 . These results were nearly identical to the reference values and could be attributed to the physiochemical reactions of artificial pozzolans and their finer texture. Erhart et al. (2014) also related that increases in strength can also be attributed to the high pozzolanic nature of RHA and FA while Mehta and Monteiro (2014) noted that artificial pozzolan addition reduced the porosity of the cement paste, increased its compaction and further refined calcium hydroxide grains.

\section{Elasticity modulus}

Elasticity modulus is affected by CDW having higher porosity while at the same time having a lower deformation modulus than natural aggregates due to its low capacity to resist matrix deformations. Consequently, NBR 8522 (ABNT, 2017) guidelines stated the need for determining static elasticity and deformation to compression. For this study, a total of 40 test specimens were tested after 28 days curing. From these, only concrete mixtures with elasticity modules higher than $37.78 \mathrm{GPa}$ and $43.34 \mathrm{GPa}$ were within the parameters, considering the defined characteristic of $25 \mathrm{MPa}$ and $35 \mathrm{MPa}$ (31.6 $\mathrm{MPa}$ and 41.6 MPa after 28 days, respectively). Results are shown in Figure 4 and Table 8.

Table 8 shows that most concrete mixtures were not able to meet the elasticity modulus of $37.78 \mathrm{GPa}$ and 43.34 GPa predicted by NBR 6118 (ABNT, 2014). This could be attributed to the larger deformation characteristic of CDWs when compared to natural aggregates. This result was also reported by Angulo (2005) and Poon, Qiao and Chan (2006). Substitution of Portland cement with $25 \%$ w.t. of supplementary cementitious materials improved results, where the substitution by rice husk ash resulted in differences of $+4.91 \%$ and $-13.20 \%$ in elasticity modulus when used with $15 \%$ w.t. and $20 \%$ w.t. CDW substitution, respectively. In comparison, the substitution by fly ash resulted in differences of $-3.35 \%$ and $-16.38 \%$ in elasticity modulus when used with $15 \%$ w.t. and $20 \%$ w.t. CDW substitution, respectively. However, 
Almeida (2005) stated that elasticity modulus variation was not proportional to increases in compressive strength.

The CP V - ARI reference sample had an elasticity modulus difference of $+3.46 \%$ with respect to NBR 6118 (ABNT, 2014). Samples with $15 \%$ w.t. and $30 \%$ w.t. CDW substitution had differences of $+2.09 \%$ and $14.53 \%$, respectively. On the other hand, no CP IV cement mixture was able to meet the predictions: the reference sample had a difference of $-14.29 \%$ while samples with $15 \%$ w.t. and $30 \%$ w.t. CDW substitution had differences of $-21.81 \%$ and $-29.46 \%$, respectively. These results were in accordance with Hui-Sheng, Bi-Wan amd Xiao-Chen (2009), Padmini, Ramamurthy and Mathews (2009) and Safiuddin et al. (2011) and were a reflection of recycled aggregates which were more porous and resulted in decreases in modulus of elasticity as the substitution rate increased. Gómez-Soberón (2002) also verified that a decrease in elasticity modulus was related to an increase in its porosity. Fonseca, Brito and Evangelista (2011) stated that the elasticity modulus of concrete was highly dependent on the rigid phases (aggregates, cement paste and transition zone) while Dal Molin (2005) considered aggregate characteristics the limiting factor.

\section{Chloride Penetration under Immersion}

Chloride penetration under immersion was studied by immersing the specimens in saline solution similar to seawater $(31.94 \mathrm{~g} \mathrm{NaCl}$ per litre of distilled water) for four distinct periods: 28 days, 56 days, 84 days and 112 days. Four surfaces were analysed from each specimen to obtain an average penetration depth. Results are shown in Table 9.

Table 9 does not show significant differences in penetration depths between mixtures of CP IV - 32 and CP $\mathrm{V}$ - ARI cement. However, the ANOVA analysis shown in Table 10 proves no significant statistical difference occurs in the penetration depth with respect to the cement type.

Figure 4 - Elasticity modulus of concrete mixtures after 28 days

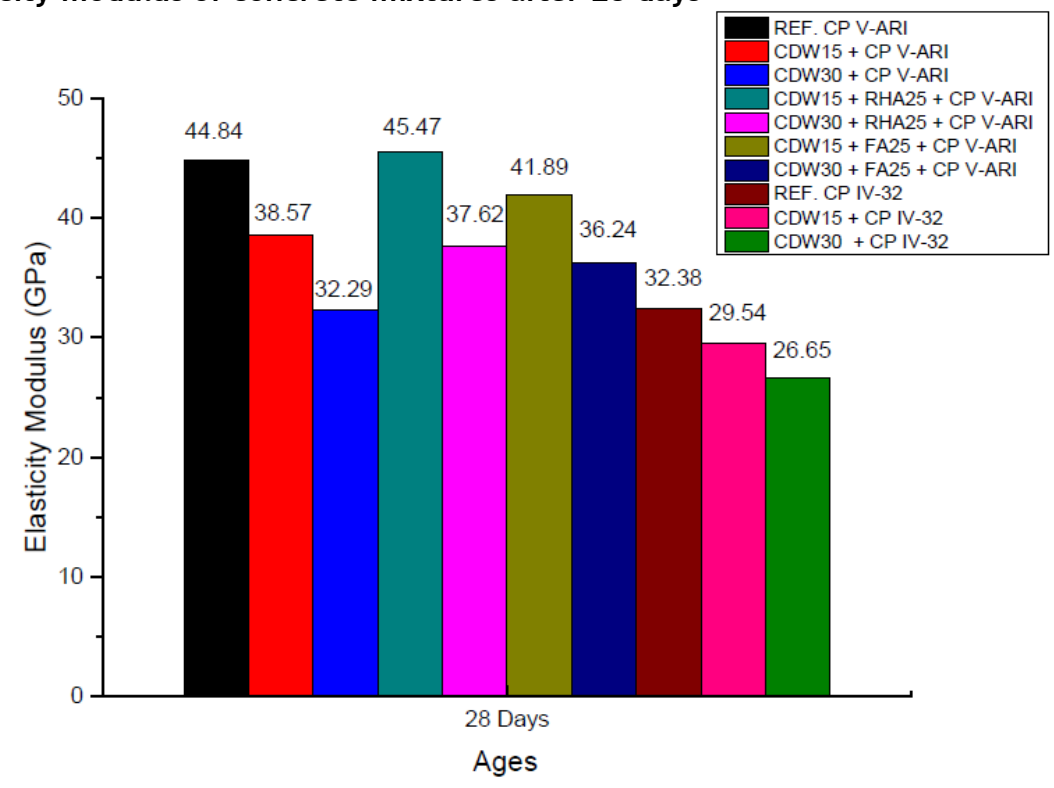

Table 8 - Comparison of measured elasticity modulus and predicted by NBR 6118 (ABNT, 2014)

\begin{tabular}{l|c|c|c|c}
\hline \multicolumn{1}{c}{ Concrete mixtures } & \multicolumn{3}{|c|}{ Elasticity Modulus (GPa) } & \multirow{2}{*}{ Difference (\%) } \\
\cline { 2 - 5 } & Specimens & Standard Deviation & NBR 6118 (2014) & \\
\hline REF. CP V - ARI & 44.84 & 1.366 & 43.34 & +3.46 \\
CDW 15 + CP V - ARI & 38.57 & 0.755 & 37.78 & +2.09 \\
CDW 30 + CP V - ARI & 32.29 & 0.488 & 37.78 & -14.53 \\
CDW 15 + RHA 25 + CP V - ARI & 45.47 & 0.400 & 43.34 & +4.91 \\
CDW 30 + RHA 25 + CP V - ARI & 37.62 & 1.109 & 43.34 & -13.20 \\
CDW 15 + FA 25 + CP V - ARI & 41.89 & 0.708 & 43.34 & -3.35 \\
CDW 30 + FA 25 + CP V - ARI & 36.24 & 0.240 & 43.34 & -16.38
\end{tabular}

184 Lima, C. J. F. de; Ribeiro, F. R. C.; Isaia, G. C.; Mancio, M. 
REF. CP IV - 32

CDW $15+$ CP IV - 32

CDW $30+$ CP IV - 32
32.38

29.54

26.65
0.555

0.615

0.294
37.78

37.78

37.78
$-14.29$

$-21.81$

$-29.46$

\begin{tabular}{|c|c|c|c|c|c|c|c|c|c|c|}
\hline \multirow{3}{*}{ Concrete mixtures } & \multirow{2}{*}{\multicolumn{2}{|c|}{$\begin{array}{l}\text { Average compressive } \\
\text { strength (MPa) }\end{array}$}} & \multicolumn{8}{|c|}{ Age (days) } \\
\hline & & & \multicolumn{2}{|c|}{28} & \multicolumn{2}{|c|}{56} & \multicolumn{2}{|c|}{84} & \multicolumn{2}{|c|}{112} \\
\hline & $\mathbf{f c}_{28}$ & $\mathbf{w} / \mathbf{b}$ & \begin{tabular}{|c|} 
Depth \\
$(\mathbf{m m})$
\end{tabular} & SD & $\begin{array}{c}\text { Depth } \\
(\mathbf{m m})\end{array}$ & SD & $\begin{array}{c}\text { Depth } \\
(\mathbf{m m})\end{array}$ & SD & $\begin{array}{c}\text { Depth } \\
(\mathrm{mm})\end{array}$ & SD \\
\hline REF. CP V - ARI & 40.17 & 0.54 & 8.23 & 0.470 & 11.18 & 0.639 & 14.36 & 0.821 & 16.80 & 0.960 \\
\hline CDW $15+\mathrm{CP}$ V - ARI & 30.59 & 0.55 & 8.25 & 0.539 & 11.35 & 0.741 & 14.47 & 0.945 & 17.50 & 1.143 \\
\hline CDW $30+\mathrm{CP}$ V - ARI & 30.25 & 0.42 & 9.37 & 0.689 & 12.98 & 0.954 & 15.98 & 1.174 & 19.77 & 1.453 \\
\hline $\begin{array}{l}\text { CDW } 15+\text { RHA } 25+ \\
\text { CP V - ARI }\end{array}$ & 40.64 & 0.62 & 7.35 & 0.420 & 9.70 & 0.554 & 12.31 & 0.704 & 15.67 & 0.896 \\
\hline $\begin{array}{l}\text { CDW } 30+\text { RHA } 25+ \\
\text { CP V - ARI }\end{array}$ & 40.25 & 0.53 & 7.84 & 0.448 & 10.19 & 0.582 & 13.55 & 0.774 & 16.94 & 0.968 \\
\hline $\begin{array}{l}\text { CDW } 15+\text { FA } 25+ \\
\text { CP V - ARI }\end{array}$ & 40.80 & 0.57 & 7.62 & 0.498 & 10.26 & 0.670 & 13.52 & 0.883 & 15.63 & 1.021 \\
\hline $\begin{array}{l}\text { CDW } 30+\text { FA } 25+ \\
\text { CP V - ARI }\end{array}$ & 39.89 & 0.47 & 8.46 & 0.553 & 11.18 & 0.730 & 15.44 & 1.009 & 17.59 & 1.149 \\
\hline REF. CP IV - 32 & 30.32 & 0.53 & 8.95 & 0.585 & 12.12 & 0.792 & 15.10 & 0.986 & 17.94 & 1.172 \\
\hline CDW 15 + CP IV - 32 & 30.44 & 0.50 & 9.34 & 0.686 & 12.51 & 0.919 & 15.51 & 1.140 & 17.80 & 1.308 \\
\hline CDW $30+$ CP IV - 32 & 30.23 & 0.42 & 10.17 & 0.830 & 12.95 & 1.057 & 15.65 & 1.278 & 20.35 & 1.662 \\
\hline
\end{tabular}

Note: $\mathrm{SD}=$ Standard Deviation.

Table 10 - Analysis of variance of chloride ion penetration depth with respect to cement type

Terminology:

\begin{tabular}{c|c|c|c|c|c|c}
\hline Source of Variance & SS & DoF & MS & F & P-value & F $_{\text {crit }}$ \\
\hline CP IV-32 x CP V-ARI & 2.767604 & 1 & 2.767604 & 0.201832 & 0.657641 & 4.30095 \\
\hline
\end{tabular}

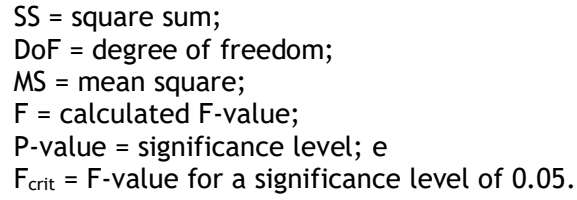

Considering the concrete mixtures that did not include cement CP IV - 32, Table 9 shows that mixtures with artificial pozzolans achieved better penetration results over all ages, with some mixtures outperforming the reference samples. Medina, Frías and Rojas (2012) and Thomas et al. (2013) hypothesised that concrete with CDW and pozzolans had improved interfaces between old and new concrete. This was a result of better adhesiveness between artificial pozzolans (such as RHA or FA) and recycled aggregates, creating a sealant able to fill pores and allow greater compaction of the mixture. It should be noted that Table 9 shows that RHA and FA had similar results even if these had distinct physio-chemical characteristics both with respect to fineness and with respect to oxide content. Rice husk ash had $0.39 \%$ w.t. of $\mathrm{Al}_{2} \mathrm{O}_{3}$ and $0.54 \%$ w.t. of $\mathrm{Fe}_{2} \mathrm{O}_{3}$ while fly ash had $25.89 \%$ w.t. of $\mathrm{Al}_{2} \mathrm{O}_{3}$ and $3.15 \%$ w.t. of $\mathrm{Fe}_{2} \mathrm{O}_{3}$. Regarding fineness and the potential to fill pores, the BET specific area of RHA was $18.71 \mathrm{~m}^{2} / \mathrm{g}$ while FA was $3.55 \mathrm{~m}^{2} / \mathrm{g}$, meaning that FHA fineness compensated its lower aluminium oxide content and vice-versa for FA. Furthermore, Wee, Suryavanshi and Tin (2000) stated that chloride penetration depended on the microstructure of concrete and its modifications, such as fixing chloride by the presence of aluminates and iron aluminate phases. Thus, substituting cement with pozzolans using low aluminate content such as RHA decreased the ability of chloride to combine with aluminates and could result in deeper penetration coefficients. However, mineral additions altered the porous structure of concrete and reduced chloride penetration and infiltration of humidity and oxygen. This increased concrete durability and contributed to chloride corrosion prevention (DAL MOLIN, 2011).

\section{Conclusions}

Reference CP V - ARI cement mixture had a measured axial compressive strength of $4.17 \mathrm{MPa}$ with a w/b ratio of 0.54 . When natural coarse aggregate was replaced with CDW in $15 \%$ w.t. and $30 \%$ w.t., average 
strengths were measured as $30.59 \mathrm{MPa}$ with a w/b ratio of 0.55 and $30.25 \mathrm{MPa}$ with w/b ratio of 0.42 , respectively. Concerning CP IV cement, the reference mixture had a measured strength of $30.32 \mathrm{MPa}$ with a w/b ratio of 0.53 and the equivalent mixtures with $15 \%$ w.t. and $30 \%$ w.t. CDW substitution had average strengths measured as $30.44 \mathrm{MPa}$ with a w/b ratio of 0.50 and $30.23 \mathrm{MPa}$ with a w/b ratio of 0.42 , respectively. These results showed that CDW substitution was detrimental to axial compressive strength, as well as longitudinal elasticity modulus.

Results also showed that the decrease in axial compressive strength from CDW use could be circumvented by using supplementary cementitious materials. Concrete mixtures with $15 \%$ w.t. and $30 \%$ w.t. CDW substitution, which had $25 \%$ w.t. cement-to-RHA substitution had measured strengths of $40.64 \mathrm{MPa}$ with a w/b ratio of 0.62 and $40.25 \mathrm{MPa}$ with w/b ratio of 0.53 , respectively. Similarly, $15 \%$ w.t. and $30 \%$ w.t. CDW substitution mixtures, which had $25 \%$ w.t. cement-to-FA substitution, had measured strengths of $40.80 \mathrm{MPa}$ with a w/b ratio of 0.57 and $39.89 \mathrm{MPa}$ with $\mathrm{w} / \mathrm{b}$ ratio of 0.47 , respectively. These results clearly showed the corrective effect of pozzolan substitution in axial compressive strength, which was also extended to longitudinal elasticity modulus, even if the effects were not proportional between these properties.

Concrete durability was evaluated through chloride penetration under immersion. Concrete mixtures with CP V - ARI cement and partial pozzolan substitution achieved the best results. Similar to natural coarse aggregate substitution with CDW which was detrimental to axial compressive strength and longitudinal modulus of elasticity, both RHA and FA substitution were shown to compensate increases in chloride penetration. These results are repeatable considering previously used materials and mixing ratios.

\section{References}

ALMEIDA, I. R. Concretos de alto desempenho. In: CONCRETO: ensino, pesquisa e realizações. São Paulo: IBRACON, 2005.

ANGULO, S. C. Caracterização de agregados de resíduos de construção e demolição reciclados e a influência de suas características no comportamento de concretos. São Paulo, 2005. Doctoral Thesis, Escola Politécnica da Universidade de São Paulo, São Paulo, 2005.

ASSOCIAÇÃO BRASILEIRA DE NORMAS TÉCNICAS. NBR 12653: materiais pozolânicos: requisitos. Rio de Janeiro, 2015a.

ASSOCIAÇÃO BRASILEIRA DE NORMAS TÉCNICAS. NBR 12655: concreto de cimento Portland: preparo, controle e recebimento: procedimento. Rio de Janeiro, $2015 \mathrm{~b}$.

ASSOCIAÇÃO BRASILEIRA DE NORMAS TÉCNICAS. NBR 5738: concreto: procedimento para moldagem e cura de corpos de prova. Rio de Janeiro, 2016.

ASSOCIAÇÃO BRASILEIRA DE NORMAS TÉCNICAS. NBR 5739: concreto: ensaios de compressão de corpos de prova cilíndricos. Rio de Janeiro, 2018.

ASSOCIAÇÃO BRASILEIRA DE NORMAS TÉCNICAS. NBR 6118: projeto de estruturas de concreto: procedimento. Rio de Janeiro, 2014.

ASSOCIAÇÃO BRASILEIRA DE NORMAS TÉCNICAS. NBR 8522: concreto: determinação do módulo estático de elasticidade a compressão. Rio de Janeiro, 2017.

BASF. Master Builders Solutions 2017. Available at: https://assets.master-builders-solutions.com/ptbr/basf\%20-

$\% 20$ manual\%20te\%CC\%81cnico\%202017\%20rev04\%20versa\%CC\%83o\%20web\%20(002).pdf. Access on: 10 jan. 2018.

BLANKENDAAL, T.; SCHUUR, P.; VOORDIJK, H. Reducing the environmental impact of concrete and asphalt: a scenario approach. Journal of Cleaner Production, v. 66, p. 27-36, 2014.

CHEN, J. et al. An empirical study on the $\mathrm{CO}_{2}$ emissions in the Chinese construction industry. Journal of Cleaner Production, v. 168, p. 645-654, 2017.

DAL MOLIN, D. C. C. Adições minerais para concreto estrutural. In: CONCRETO: ensino, pesquisa e realizações. São Paulo: IBRACON, 2005.

DAL MOLIN, D. C. C. Adições Minerais. In: CIÊNCIA e Tecnologia. São Paulo: IBRACON, 2011.

186 Lima, C. J. F. de; Ribeiro, F. R. C.; Isaia, G. C.; Mancio, M. 
DIAZ-LOYA, I. et al. Extending supplementary cementitious material resources: reclaimed and remediated fly ash and natural pozzolans. Cement and Concrete Composites, v. 101, p. 44-51, 2019.

ERHART, R. et al. Influência da cinza de casca de arroz na resistência e na absorção de água de concretos produzidos com agregados graúdos reciclados de concreto. In: CONGRESSO BRASILEIRO DE CONCRETO, 56., Natal, 2014. Proceedings [...] Natal, 2014.

FONSECA, N.; BRITO, J.; EVANGELISTA, L. The influence of curing conditions on the mechanical performance of concrete made with recycled concrete waste. Cement and Concrete Composites, v. 33, p. 637-643, 2011.

GÓMEZ-SOBERÓN, J. M. V. Porosity of recycled concrete with substitution of recycled concrete aggregate - An experimental study. Cement and Concrete Research, v. 32, p. 1301-1311, 2002.

HELENE, P. R. L.; TERZIAN, P. Manual de dosagem e controle do concreto. São Paulo: Pini, 1992.

HUANG, L. et al. Carbon emission of global construction sector. Renewable and Sustainable Energy Reviews, v. 81, p. 1906-1916, 2018.

HUI-SHENG, S.; BI-WAN, X.; XIAO-CHEN, Z. Influence of mineral admixtures on compressive strength, gas permeability and carbonation of high-performance concrete. Construction and Building Materials, v. 23, p. 1980-1985, 2009.

ISAIA, G. C. et al. Viabilidade do emprego de cinza de casca dearroz natural em concreto estrutural (parteII): durabilidade. Ambiente Construído, Porto Alegre, v. 17, n. 2, p. 233-252, abr./jun. 2017.

ISAIA, G. C.; FURQUIM, P. R. de V.; GASTALDINI, A. L. G. Análise estatística de variáveis influentes na microestrutura e durabilidade de concretos com adições minerais. Ambiente Construído, Porto Alegre, v. 9, n. 1, p. 9-23, jan./mar. 2009.

KALINOWSKA-WICHROWSKA, K.; PAWLUCZUK, E.; BOLTRYK, M. Waste-free technology for recycling concrete rubble. Construction and Building Materials, v. 234, 2020.

KOU, S.; POON, C. Effect of the quality of parent concrete on the properties of high performance recycled aggregate concrete. Construction and Building Materials, v. 77, p. 501-508, 2015.

KOU, S.C.; POON, C.S. Long-term mechanical and durability properties of recycled aggregate concrete prepared with the incorporation of fly ash. Cement and Concrete Composites, v. 37, p. 12-19, 2013.

LEITE, M. B. Avaliação das propriedades mecânicas de concretos produzidos com agregados reciclados de resíduos de construção e demolição. Porto Alegre, 2001. Doctoral Thesis - Programa de Pós-Graduação em Engenharia Civil, Universidade Federal do Rio Grande do Sul, Porto Alegre, 2001.

LI, J; XIAO, H.; ZHOU, Y. Influence of coating recycled aggregate surface with pozzolanic powder on properties of recycled aggregate concrete. Construction and Building Materials, v. 23, p. 1287-1291, 2009.

MEDINA, C. et al. Design and characterisation of ternary cements containing rice husk ash and fly ash. Construction and Building Materials, v. 187, p. 65-76, 2018.

MEDINA, C.; FRÍAS, M.; ROJAS, M. I. S. de. Microstructure and properties of recycled concretes using ceramic sanitary ware industry waste as coarse aggregate. Construction and Building Materials, v. 31, p. 112-118, 2012.

MEHTA, P. K.; MONTEIRO, P. J. M. Concreto: microestrutura, propriedades e materiais. São Paulo: Instituto Brasileiro de Concreto, 2014.

OTSUKI, N.; NAGATAKI, S.; NAKASHITA, K. Evaluation of AgNO3 solution spray Method for measurement of chloride penetration into hardener cementitious matrix materials. ACI Materials Journal, v. 89, n. $6,1992$.

PADMINI, A. K.; RAMAMURTHY, K.; MATHEWS, M. S. Influence of parent concrete on the properties of recycled aggregate concrete. Construction and Building Materials, v. 23, p. 829-836, 2009.

POON, C. S; QIAO, X. C.; CHAN, D. Feasible use of recycled concrete aggregates and crushed clay brick as unbound road sub-base. Construction and Building Materials, v. 20, p. 578-585, 2006.

RYU, J. S. An experimental study on the effect of recycled aggregate on concrete properties. Magazine of Concrete Research, v. 54, n. 1, p.7-12, 2002. 
SAFIUDDIN, M. et al. Properties of high-workability concrete with recycled concrete aggregate. Materials Research, v. 14, p. 248-255, 2011.

SANTOS, A. A. M. dos; LEITE, M. B. Avaliação de concretos reciclados com agregado graúdo de concreto dosados pelo método da ABCP modificado. Ambiente Construído, Porto Alegre, v. 18, n. 4, p. 341-359, out./dez. 2018.

SCHNEIDER, M. Process technology for efficient and sustainable cement production. Cement and Concrete Research, v. 78, p. 14-23, 2015.

SINDICATO NACIONAL DA INDÚSTRIA DO CIMENTO. Vendas de cimento consolidam crescimento. Resultados preliminares de Outubro, 2019. Disponível em: http://snic.org.br/assets/pdf/resultadospreliminares/1573224597.pdf. Access in: 10 nov. 2019.

THOMAS, C. et al. Durability of recycled aggregate concrete. Construction and Building Materials, v. 40, p. 1054-1065, 2013.

\title{
U.S. GEOLOGICAL SURVEY. Mineral Commodity Summaries 2019. 2019.
}

WANG, L. et al. An environmentally friendly method to improve the quality of recycled concrete aggregates. Construction and Building Materials, v. 144, p. 432-441, 2017.

WEE, T. H.; SURYAVANSHI, A. K.; TIN, S. S. Evaluation of rapid chloride permeability test (RCPT): results for concrete containing mineral admixtures. ACI Materials Journal, v. 97, n. 2, p. 221-232, 2000.

XUAN, D.; POON, C. S.; ZHENG, W. Management and sustainable utilization of processing wastes from ready mixed concrete plants in construction: A review. Resources, Conservation and Recycling, v. 36, p. 238-247, 2018.

\section{Acknowledgements}

The authors thank Capes (Coordenação de Aperfeiçoamento de Pessoal do Ensino Superior - Brazil) for the grants awarded for the development of this study.

Cristian Jonathan Franco de Lima

Escola Politécnica | Universidade do Vale do Rio dos Sinos | Av. Unisinos, 950, Cristo Rei | São Leopoldo - RS - Brasil | CEP $93022-750$ | Tel.: (51) 3591-1122 Ramal 1769 | E-mail: cristian.jfl@outlook.com

\section{Francisco Roger Carneiro Ribeiro}

Escola Politécnica | Universidade do Vale do Rio dos Sinos | E-mail: roger.ribeiro_@hotmail.com

\section{Geraldo Cechella Isaia}

Departamento de Estruturas e Construção Civil, Centro de Tecnologia | Universidade Federal de Santa Maria | Av. Roraima, 1000, Camobi | Santa Maria - RS - Brasil | CEP 97105-900 | Tel.: (55) 3220-8837 | E-mail: geraldoisaias@gmail.com

\section{Mauricio Mancio}

Escola Politécnica | Universidade do Vale do Rio dos Sinos | Tel.: (51) 3591-1122 Ramal 1714 | E-mail: mancio@unisinos.br

\author{
Ambiente Construído \\ Revista da Associação Nacional de Tecnologia do Ambiente Construído \\ Av. Osvaldo Aranha, $99-3^{\circ}$ andar, Centro \\ Porto Alegre - RS - Brasil \\ CEP $90035-190$ \\ Telefone: +55 (51) 3308-4084 \\ Fax: +55 (51) 3308-4054 \\ www.seer.ufrgs.br/ambienteconstruido \\ E-mail: ambienteconstruido@ufrgs.br
}

